\title{
Faktor-Faktor yang Berhubungan dengan Terjadinya Penyakit Infeksi Saluran Pernafasan Akut (ISPA) di Puskesmas Pintupadang Kecamatan Batang Angkola Kabupaten Tapanuli Selatan Tahun 2020
}

\author{
Rahmat Rizki Siregar
}

Program Studi Keperawatan, Institut Teknologi dan Kesehatan Sumatera Utara

\section{Info Artikel}

\section{Article history:}

Diterima 11-06-2021

Revisi 29-06-2021

Disetujui 13-07-2021

\section{Kata kunci:}

ISPA,

Pengetahuan,

Ekonomi,

Kebiasan Merokok.

\begin{abstract}
A B S T R A K
ISPA (Infeksi Saluran Pernapasan Akut) adalah penyakit saluran pernapasan akut dengan perhatian khusus pada radang paru (pneumonia) dan bukan penyakit telinga dan tengorokan. Penyakit ISPA merupakan yang dapat menimbulkan kematian pada belita atau anak usia 5 tahun kebawah. Penelitian ini bersipat deskriptif analitik, metode pengumpulan data dengan mengunakan alat yaitu questioner. Sampel dalam penelitian ini berjumlah 35 orang. Pengolahan data dilakukan dengan beberapa tahapan yaitu: analisis univariat untuk menggambarkan distribusi frekuensi dari masing-masing variabel, analisis bivariat untuk melihat hubungan Pengetahuan, Kebiasaan Merokok dan tingkat Ekonomi dengan penyakit saluran pernapasan akut (ISPA) menggunakan Chi-Square. Hasil uji statistik pengetahuan responden terhadap ISPA diperoleh $\mathrm{P}=0.97$ ( $\mathrm{p}>0.05$ ) artinya H0 diterima dan Ha ditolak menunjukkan tidak ada hubungan yang signifikan antara faktor pengetahuan terhadap infeksi saluran pernapasan akut (ISPA). Uji statistik Ekonomi responden diperoleh nilai $\mathrm{P}=0.20(\mathrm{P}>0.05)$ artinya $\mathrm{H} 0$ diterima dan $\mathrm{Ha}$ ditolak ditolak menunjukkan tidak ada hubungan yang signifikan antara faktor ekonomi dengan infeksi saluran pernapasan akut (ISPA), uji statistik kebiasaan merokok responden diperoleh nilai $\mathrm{P}=0.01(\mathrm{P}=<0.05)$ artinya $\mathrm{H} 0$ ditolak dan Ha diterima hal ini menunjukkan terdapat hubungan yang signifikan antara faktor kebiasaan merokok dengan kejadian ISPA. Adapun saran program promotif dan preventif terhadap penyakit ISPA yang telah ada hendaknya dilaksanakan sefektif mungkin, agar angka kasus ISPA di Kecamatan Batang Angkola Kabupaten Tapanuli Selatan berkurang.
\end{abstract}

\section{Koresponden Penulis:}

Rahmat Rizki Siregar,

Program Studi Keperawatan, Institut Teknologi dan Kesehatan Sumatera Utara,

Jl. Trans Sumatera Bukittinggi - Padang Sidempuan, Sihitang, Padangsidimpuan Tenggara, Kota Padang

Sidempuan, Sumatera Utara 22733.

Email: siregarrizki01@gmail.com

\section{PENDAHULUAN}

Pencemaran udara dapat ditimbulkan oleh sumber-sumber alami maupun kegiatan manusia. Beberapa definisi gangguan fisik seperti polusi suara, panas, radiasi atau polusi cahaya dianggap sebagai polusi udara. Sifat alami udara mengakibatkan dampak pencemaran udara dapat bersifat langsung dan lokal, regional, maupun global. Pencemaran udara di Indonesia dapat kita lihat, yaitu semakin banyaknya pembangunan - pembangunan gedung - gedung bertingkat, monorel untuk mengurangi kemacetan sehingga banyak pohon-pohon yang di tebang, kendaraan bermotor yang makin meningkat sehingga asap-asap kendaraan mencemari udara, banyaknya penebangan hutan untuk membuat bangunan tempat tinggal yang mewah sehingga sumber oksigen berkurang, banyaknya masyarakat yang membuang sampah sembarangan sehingga mencemari air. Semua hal tersebut adalah sebagian kegiatan atau fenomena yang ada dalam pencemaran udara, dimana semua itu akan menyebabkan gangguan pada kesehatan manusia itu sendiri (Depkes RI. 2002). 
Salah satu penyakit yang paling banyak diderita oleh masyarakat adalah ISPA (Infeksi Saluran Pernapasan Akut). Sebagian besar dari infeksi saluran pernapasan hanya bersifat ringan seperti batuk-pilek, disebabkan oleh virus, dan tidak memerlukan pengobatan dengan antibiotik. Infeksi saluran pernapasan bagian atas terutama yang disebabkan oleh virus, sering terjadi pada semua golongan masyarakat pada bulan-bulan musim dingin. Penyakit ISPA merupakan penyakit yang sering terjadi pada anak, karena sistem pertahanan tubuh anak masih rendah.

ISPA merupakan singkatan dari Infeksi Saluran Pernapasan Akut, istilah ini diadaptasikan dari istilah dalam bahasa inggris Acute Respiratory Infection (ARI). Penyakit infeksi akut yang menyerang salah salah satu bagian dan atau lebih dari saluran napas mulai dari hidung (saluran atas) hinga alveoli (saluran bawah) termasuk jaringan adneksanya seperti sinus,rongga telingga tengah dan pleura . penyakit ISPA merupakan penyakit yang sering terjadi pada anak, karena sistem pertahanan tubuh anak masih rendah. (Gede PurnamaS, 2016).

Di Indonesia penyakit Infeksi Saluran Pernafasan Akut (ISPA) merupakan penyakit yang sering terjadi pada anak. Episode penyakit batuk pilek pada balita di Indonesia diperkirakan sebesar 3 sampai 6 kali pertahun. Ini berarti seorang balita rata-rata mendapat serangan batuk, pilek sebanyak 3 sampai 6 kali setahun. Sebagai kelompok penyakit, ISPA juga merupakan salah satu penyebab utama kunjungan pasien disarana kesehatan. Sebanyak 40\%-60\% kunjungan berobat dipuskesmas dan 15\%-30\% kunjungan berobat dibagian rawat jalan dan rawat inap rumah sakit disebabkan oleh ISPA (DepKes.RI, 2009).

Menurut WHO tahun 2012, sebesar 78\% balita yang berkunjung ke pelayanan kesehatan adalah akibat ISPA, khususnya pneumonia. ISPA lebih banyak terjadi di negara berkembang dibandingkan negara maju dengan persentase masing-masing sebesar $25 \%-30 \%$ dan $10 \%-15 \%$. Kematian balita akibat ISPA di Asia Tenggara sebanyak 2.1 juta balita pada tahun 2004 (Fitri, 2012).

Kematian balita akibat ISPA di Indonesia mengalami peningkatan sebesar 20.6\% dari tahun 2010 hingga tahun 2011 yaitu 18.2\% menjadi 38.8\% (Layuk dan Noer, 2015).

Berdasarkan survey pendahuluan yang dilakukan peneliti di Puskesmas Pintupadang Kecamatan Batang Angkola Kabupaten Tapanuli Selatan pada bulan September dan Oktober tahun 2020 terdapat 137 orang yang mengalami penyakit Infeksi Saluran Pernapasan Akut.

Tujuan penelitian Ini adalah untuk menganalisis Faktor - Faktor Yang Berhubungan Dengan Terjadinya Penyakit Infeksi Saluran Pernapasan Akut (Ispa) Di Puskesmas Pintupadang Kecamatan Batang Angkola Kabupaten Tapanuli Selatan Tahun 2020.

\section{METODE PENELITIAN}

Jenis penelitian ini adalah bersifat deskriptif analitik dengan rancangan penelitian cross sectional. Dimana suatu penelitian bertujuan untuk mempelajari dinamika korelasi antara faktorfaktor risiko dengan efek, dengan cara pendekatan, observasi atau pengumpulan data sekaligus pada saat yang sama (Notoadmodjo, 2012), dengan tujuan untuk menganalisis faktor-faktor yang berhubungan dengan terjadinya Penyakit Infeksi Saluran Pernafasan Akut (Ispa) Di Puskesmas Pintupadang Kecamatan Batang Angkola Kabupaten Tapanuli Selatan.

Data primer adalah data yang dikumpulkan secara langsung oleh peneliti diperoleh dengan penyebaran kuisioner. Data sekunder diperoleh dari laporan-laporan maupun dokumen-dokumen resmi lainnya yang digunakan untuk membantu analisis terhadap data primer yang diperoleh.

Pengolahan data akan dilakukan dengan tahapan sebagai berikut :

1. Analisis univariat yaitu analisis yang menitik beratkan kepada penggambaran atau deskripsi data yang diperoleh, menggambarkan distribusi frekuensi dari masing-masing variabel independen dan dependen.

2. Analisis bivariat yaitu untuk melihat ada tidaknya hubungan pengetahuan, tingkat ekonomi, dan kebiasaan merokok dengan kejadian penyakit infeksi saluran Pernafasan Akut (ISPA) menggunakan uji Chi-Square.

\section{HASIL DAN PEMBAHASAN \\ 3.1. Hasil \\ Analisia Univariat}

Faktor-Faktor yang Berhubungan dengan Terjadinya Penyakit Infeksi Saluran ... ( Rahmat Rizki Siregar) 
Distribusi Frekuensi Pengetahuan Responden tentang Infeksi Saluran Pernapasan Akut (ISPA) di Puskesmas Pintupadang Kecamatan Batang Angkola Kabupaten Tapanuli Selatan Tahun 2021.

Analisis ini dilakukan untuk melihat tingkat pengetahuam responden tentang penyakit Infeksi Saluran Pernapasan Akut (ISPA) di Puskesmas Pintupadang Kecamatan Batang Angkola Kabupaten Tapanuli Selatan Tahun 2020.

Tabel 1. Distribusi Frekuensi Pengetahuan Responden tentang Infeksi Saluran Pernapasan Akut (ISPA)

$\begin{array}{ccc}\text { Pengetahuan } & \text { F } & \text { \% } \\ \text { Baik } & 3 & 8,6 \% \\ \text { Cukup } & 18 & 51,4 \% \\ \text { Kurang } & 14 & 40,0 \% \\ \text { Jumlah } & \mathbf{3 5} & \mathbf{1 0 0 \%}\end{array}$

Tabel 2 di atas menunjukkan bahwa dari 35 responden yang diteliti berdasarkan kebiasan merokok, Responden Yang merokok sebanyak 20 orang $(57,1 \%)$, dan Responden yang tidak merokok sebanyak 15 orang $(42,9 \%)$.

Distribusi Frekuensi Responden Berdasarkan Faktor Ekonomi di Puskesmas Pintupadang Kecamatan Batang Angkola Kabupaten Tapanuli Selatan Tahun 2021

Tabel 3. Distribusi Frekuensi Responden berdasarkan Tingkat Ekonomi

\begin{tabular}{ccc} 
Ekonomi & F & \% \\
Rendah & 24 & 68,6 \\
Menengah & 7 & 20,0 \\
Tinggi & 4 & 11,4 \\
Jumlah & $\mathbf{3 5}$ & $\mathbf{1 0 0}$ \\
\hline
\end{tabular}

Tabel 3 di atas menunjukkan bahwa dari 35 responden yang diteliti, berdasarkan faktor Ekonomi, responden dengan tingkat ekonomi rendah sebanyak 24 orang $(68,6 \%)$, yang berekonomi menengah sebanyak 7 orang $(20,0 \%)$, dan berekonomi tinggi sebanyak 4 orang $(11,4 \%)$.

Distribusi Frekuensi Responden Berdasarkan Faktor Infeksi Saluran Pernapasan Akut (ISPA) di Puskesmas Pintupadang Kecamatan Batang Angkola Kabupaten Tapanuli Selatan Tahun 2021.

Tabel 4. Distribusi Frekuensi Responden berdasarkan faktor infeksi

\begin{tabular}{ccc}
\hline Penyakit ISPA & F & \% \\
Ya & 22 & 62,9 \\
Tidak & 13 & 37,1 \\
Jumlah & 35 & 100 \\
\hline
\end{tabular}

Dari tabel 4 di atas menunjukkan bahwa dari 35 responden yang diteliti berdasarkan Penyakit ISPA, Responden Penyakit ISPA sebanyak 22 orang (62,9\%), Responden yang tidak Penyakit ISPA sebanyak 13 orang $(37,1 \%)$.

\section{Analisis Bivariat}

1. Hubungan antara tingkat pengetahuan responden dengan terjadinya Penyakit Infeksi Saluran Penafasan Akut (ISPA)

\begin{tabular}{cllllllll}
\hline & \multicolumn{9}{c}{ Penyakit ISPA } & & & \\
Pengetahuan & \multicolumn{3}{c}{ Ya } & \multicolumn{1}{c}{ Tidak } & jlh & \% & $\boldsymbol{p}$ \\
& \multicolumn{1}{c}{ F } & \multicolumn{1}{c}{$\boldsymbol{\%}$} & F & $\mathbf{\%}$ & & & \\
Baik & 2 & 5.7 & 1 & 2.9 & 3 & 8.6 & 0,97 \\
Cukup & 11 & 31.4 & 7 & 20.0 & 18 & 51.4 & \\
Kurang & 9 & 25.7 & 5 & 14.3 & 14 & 40.0 & \\
Jumlah & $\mathbf{2 2}$ & $\mathbf{6 2 . 8}$ & $\mathbf{1 3}$ & $\mathbf{3 7 . 2}$ & $\mathbf{3 5}$ & $\mathbf{1 0 0}$ & \\
\hline
\end{tabular}

Berdasarkan tabel 4.3.1 di atas dapat dilihat dari 35 orang responden, terdapat 3 orang $(8.6 \%)$ responden yang berpengetahuan baik yang penyakit Infeksi saluran pernapasan akut (ISPA) sebanyak 2 orang (5.7\%) dan yang tidak penyakit infeksi saluran pernapsan akut (ISPA) sebanyak 1orang $(2.9 \%)$. Dari 18 Orang $(51.4 \%)$ Responden yang berpengetahuan Cukup Terdapat 11 
Responden Yang penyakit infeksi saluran pernapasan akut (ISPA) Dan 7 Responden (20.0\%) yang Tidak penyakit infeksi saluran pernapasan akut (ISPA). Kemudian Terdapat 14 orang (40.0) responden yang berpengetahuan kurang terdapat 9 orang (25.7) Responden yang penyakit infeksi saluran pernapasan akut (ISPA) dan yang tidak penyakit infeksi saluran pernapasan kaut (ISPA) sebayak 5 orang $(14.3 \%)$.

Berdasarkan uji Statistik diperoleh nilai $\mathrm{P}=0,97 \quad(\mathrm{P}>0,05)$ artinya $\mathrm{H} 0$ diterima dan $\mathrm{Ha}$ ditolak jadi tidak Ada hubungan antara tingkat Pengetahuan dengan terjadinya Infeksi Saluran Pernapasan Akut (ISPA) Di Puskesmas Pintupadang Kecamatan Batang Angkola Kabupaten Tapanuli Selatan Tahun 2020.

2. Hubungan Antara Faktor Ekonomi Responden Dengan Terjadinya Penyakit Infeksi Saluran Penafasan Akut (ISPA).

\begin{tabular}{lccccccc}
\hline \multicolumn{1}{c}{ Ekonomi } & \multicolumn{9}{c}{ Penyakit ISPA } & Tidak & Total & \% & $p$ \\
Rendah & F & $\mathbf{\%}$ & F & \% & & & \\
Menengah & 17 & 48.6 & 7 & 20.0 & 24 & 68.6 & 0,20 \\
Tinggi & 4 & 11.4 & 3 & 8.6 & 7 & 20.0 & \\
& 1 & 2.9 & 3 & 8.6 & 4 & 11.4 & \\
\hline
\end{tabular}

Berdasarkan tabel 4.3.2 di atas dapat dilihat dari 35 orang responden, terdapat 24 orang $(68.6 \%)$ responden yang ekonomi $<1.982 .750$ yang penyakit Infeksi saluran pernapasan akut (ISPA) sebanyak 17 orang $(48.6 \%)$ dan yang tidak penyakit infeksi saluran pernapasan akut (ISPA) sebanyak 7 orang (20.0\%). Dari 7 Orang (20.0\%) Responden yang ekonomi 1.982 .750 yang terdapat 4 orang (11.4\%) Responden Yang penyakit infeksi saluran pernapasan akut (ISPA) Dan 73 Responden $(8.6 \%)$ yang Tidak penyakit infeksi saluran pernapasan akut (ISPA). Kemudian Terdapat 4 orang (11.4) responden yang ekonomi $>1.982 .750$ terdapat 1 orang (2.9\%) Responden yang penyakit infeksi saluran pernapasan akut (ISPA) dan yang tidak penyakit infeksi saluran pernapsaan kaut (ISPA) sebayak 3 orang $(8.6 \%)$.

Berdasarkan uji Statistik diperoleh nilai $\mathrm{P}=0,20 \quad(\mathrm{P}>0,05)$ artinya $\mathrm{H} 0$ diterima dan $\mathrm{Ha}$ ditolak jadi tidak Ada hubungan ekonomi terhadap terjadinya Infeksi Saluran Pernapasan Akut (ISPA) Di Puskesmas Pintupadang Kecamatan Batang Angkola Kabupaten Tapanuli Selatan Tahun 2020.

3. Hubungan Antara Kebiasaan Merokok Dengan Terjadinya Penyakit Infeksi Saluran Penafasan Akut (ISPA).

\begin{tabular}{ccccccccc}
\hline $\begin{array}{c}\text { Kebiasaan } \\
\text { Merokok }\end{array}$ & \multicolumn{9}{c}{ Yenyakit ISPA } & Tidak & Total & \% & $p$ \\
Ya & 9 & 25.7 & 11 & 31.4 & 20 & 57.1 & 0,01 \\
Tidak & 13 & 37.2 & 2 & 5.7 & 15 & 42.9 & \\
& $\mathbf{2 2}$ & $\mathbf{6 2 . 8}$ & $\mathbf{1 3}$ & $\mathbf{3 7 . 2}$ & $\mathbf{3 5}$ & $\mathbf{1 0 0}$ & \\
\hline
\end{tabular}

Berdasarkan tabel di atas dapat dilihat dari 35 orang responden, terdapat 20 orang $(57.1 \%)$ responden yang mengkonsumsi rokok penyakit Infeksi saluran pernapasan akut (ISPA) sebanyak 9 orang $(25.7 \%)$ dan yang tidak mengkonsumsi rokok penyakit infeksi saluran pernapasan akut (ISPA) sebanyak 11 orang $(31.4 \%)$. Kemudian Terdapat 15 orang (42.9\%) responden yang mengkonsumsi rokok terdapat 13 orang $(37.2 \%)$ Responden yang penyakit infeksi saluran pernapasan akut (ISPA) dan yang tidak penyakit infeksi saluran pernapsaan kaut (ISPA) sebayak 2 orang (5.7\%).

Berdasarkan uji Statistik diperoleh nilai $\mathrm{P}=0,01 \quad(\mathrm{P}<0,05)$ artinya $\mathrm{H} 0$ ditolak dan $\mathrm{Ha}$ diterima jadi Ada hubungan kebiasaan merokok dengan terjadinya Infeksi Saluran Pernapasan Akut (ISPA) Di Puskesmas Pintupadang Kecamatan Batang Angkola Kabupaten Tapanuli Selatan Tahun 2020.

\section{KESIMPULAN}

Mayoritas responden berpengetahuan cukup sebanyak 11 orang (31.4\%) dan minoritas responden berpengetahuan baik sebanyak 1 orang (2.9\%). Berdasarkan uji Statistik diperoleh tidak 
Ada hubungan Pengetahuan dengan terjadinya Infeksi Saluran Pernapasan Akut (ISPA) Di Puskesmas Pintupadang Kecamatan Batang Angkola Kabupaten Tapanuli Selatan. Mayoritas responden berekonomi Rendah sebanyak 17 orang (48.6\%) dan minoritas responden berekonomi Tinggi sebayak 1 orang $(2.9 \%)$. Berdasarkan uji Statistik diperoleh hasil bahwa tidak Ada hubungan faktor ekonomi dengan terjadinya Infeksi Saluran Pernapasan Akut (ISPA) Di Puskesmas

Pintupadang Kecamatan Batang Angkola Kabupaten Tapanuli Selatan. Mayoritas responden memiliki kebiasaan sebanyak 20 orang $(57,1 \%)$, dan responden tidak merokok sebanyak 15 orang $(42,9 \%)$. Berdasarkan uji Statistik diperoleh hasil yang menunjukkan bahwa terdapat Hubungan antara kebiasaan merokok dengan terjadinya Infeksi Saluran Pernapasan Akut (ISPA) Di Puskesmas Pintupadang Kecamatan Batang Angkola Kabupaten Tapanuli Selatan.

\section{REFERENSI}

Darmawan 2000. Infeksi Saluran Pernapasan Akut (Ispa). Egc. Jakarta.

Depkes RI 2012. Profil Kesehatan. Jakarta.

Depkes RI 2009. Sistem Kesehatan Nasioanal. Jakarta.

Dinkes Prov Sumut 2018. Profil Kesehatan Provensi Sumatera Utara.

Febiani, Tesa Dkk. 2007. Banjir Dan Tanah. Jakarta.

Gusti Ayu Putri.2017. Faktor-Faktor Yang Mempengaruhi Kejadian Ispa Pada Belita.Stikes Bhakti Husada Mulia.Medium.

Kemenkes RI.2016. Pedoman Pencegahan Dan Pengendalian Infeksi Saluran Pernapasan Akut (Ispa). Jakarta. Muttaqin.2008. Infeksi Saluran Pernapasan Akut. Egc. Jakarta.

Musnadiarly.2008. Infekse Saluran Pernapasan Pneumonia Pada Anak Belita Orang Dewasa Dan Usia Lanjut.Pustaka Obor Populer. Jakarta.

Prathama 2001. Perilaku Dalam Organisi. Erlangga. Jakarta.

Prabu, Putra.2009. Rumah Sehat Dan Perilaku Sehat.Rineka Cipta.Jakarta.

R.Hartono. Dwi Rahmawati H. 2012. Gangguan Pernapasan Pada Anak .Nuha Medika.Yogyakarta.

Rusnaini. 2013. Faktor-Faktor Yang Mempengaruhi Penyakit Ispa Pada Masyarakat. Universitas Teuku Umar.

Rahmayatul Fillacano. 2013. Hubungan Lingkungan Dalam Rumah Terhadap Ispa Pada Belita. Uin Syarif Hidayutullah. Jakarta.

Siti Namira. 2013. Gambaran Faktor-Faktor Yang Mempengaruhi Kejadian Ispa Pada Anak Prasekolah.Uin Syarif Hidayutullah. Jakarta. 